\title{
ANALISIS PENERIMAAN PAJAK REKLAME KABUPATEN MAGELANG DENGAN PENDEKATAN VECM PERIODE 2010 - 2014
}

\author{
Lisa Dwi Mardiana, Nano Prawoto \\ Fakultas Ekonomi Universitas Muhammadiyah Yogyakarta \\ Jl. Lingkar Selatan, Tamantirto, Kasihan, Bantul \\ Daerah Istimewa Yogyakarta 55184 \\ Email korespondensi: lisadwi513@gmail.com
}

Naskah Diterima: Juli 2016; Disetujui: Oktober 2016

\begin{abstract}
The objectives of this research are to analyze the influence of PDRB, the number of SIUP and industries towards the advertisement tax revenues in District of Magelang. The data used in this research are monthly-secondary data which is taken from the data in 2010:M082014:M12. Analysis model used in this research is regression model VECM using the assistance of software EVIEWS 7.2. VECM model is chosen in this research since it is hoped to be able to explain behavioral research variables in the long-term. Moreover, variable of PDRB and the number of SIUP have influence towards the advertisement tax revenues in District of Magelang. PDRB and the number of SIUP have stability connection or in balance and the same movement in long-term. In other words, they, in any short-term period, are likely to adjust to each other in order to achieve long-term equilibrium. At the same time, the number of industries has no any influences towards the advertisement tax revenues because not all industries located in the District of Magelang put up the advertisement to promote goods or services.
\end{abstract}

Keywords: advertisement tax, industry, VECM

JEL Classification: E62, L50, C32

Abstrak: Tujuan dari penelitian ini adalah untuk menganalisis pengaruh PDRB, jumlah SIUP dan industri terhadap pendapatan pajak iklan di Kabupaten Magelang. Data yang digunakan dalam penelitian ini adalah data sekunder bulanan yang diambil dari data tahun 2010: M082014: M12. Model analisis yang digunakan dalam penelitian ini adalah model regresi VECM dengan menggunakan bantuan perangkat lunak EVIEWS 7.2. Model VECM dipilih dalam penelitian ini karena diharapkan dapat menjelaskan variabel penelitian perilaku dalam jangka panjang. Selain itu, variabel PDRB dan jumlah SIUP berpengaruh terhadap pendapatan pajak iklan di Kabupaten Magelang. PDRB dan jumlah SIUP memiliki hubungan stabilitas atau seimbang dan pergerakan yang sama dalam jangka panjang. Dengan kata lain, mereka, dalam periode jangka pendek, cenderung menyesuaikan diri satu sama lain untuk mencapai ekuilibrium jangka panjang. Pada saat bersamaan, jumlah industri tidak berpengaruh terhadap pendapatan pajak iklan karena tidak semua industri yang berada di Kabupaten Magelang memasang iklan untuk mempromosikan barang atau jasa.

Kata kunci: advertisement tax, industry, VECM

Klasifikasi JEL: E62, L50, C32 


\section{PENDAHULUAN}

Pembangunan di Indonesia diarahkan untuk mewujudkan masyarakat yang adil dan makmur. Tujuan pembangunan ekonomi nasional adalah untuk mencapai pertumbuhan ekonomi yang tinggi dengan cara memanfaatkan potensi dan sumber daya yang ada. Akan tetapi pertumbuhan ekonomi yang tinggi belum tentu mencerminkan meningkatnya kesejahteraan semua penduduk. Tujuan utama pembangunan ekonomi daerah adalah mencapai pertumbuhan yang setinggitingginya, selain itu juga berupaya menghapus atau mengurangi tingkat kemiskinan, meningkatkan pemerataan pendapatan, dan mengurangi tingkat pengangguran dengan cara menciptakan kesempatan kerja atau perluasan lapangan kerja bagi penduduk, agar setiap penduduk berkesempatan untuk menyejahterakan kehidupannya (Todaro dan Smith, 2004).

Pembangunan dibidang ekonomi bertujuan untuk meningkatkan taraf hidup masyarakat, tingkat kemakmuran semakin tinggi, ketimpangan pendapatan semakin berkurang, kesempatan kerja semakin terbuka dan juga kualitas sumber daya manusia semakin membaik. Untuk mengetahui seberapa jauh keberhasilan pembangunan dibidang ekonomi yang telah dilaksanakan maka diperlukan adanya alat yang dapat membantu memberikan gambaran tingkat keberhasilan pembangunan dibidang ekonomi tersebut.

Penyelenggaraan otonomi daerah berimplikasi pada pengelolaan keuangan dengan meningkatkan Pendapatan Asli Daerahnya. PAD sendiri terbentuk dari elemen pajak dan retribusi daerah, laba BUMD dan lain - lain Pendapatan yang sah. Pajak yang merupakan pungutan wajib, biasanya berupa uang yang harus dibayar oleh penduduk sebagai sumbangan wajib kepada negara atau pemerintah sehubungan dengan pendapatan, pemilikan, jual beli barang, dsb.
Terdapat satu jenis pajak yang menarik dari semua pajak yang dikelola oleh pemerintah Kabupaten Magelang, yaitu pajak reklame. Pajak reklame adalah pajak atas penyelenggaraan reklame. Reklame adalah benda, alat, pembuatan, dan atau media yang bentuk dan corak ragamnya dirancang untuk tujuan komersial memperkenalkan, menganjurkan, mempromosikan, atau untuk menarik perhatian umum terhadap barang, jasa, orang atau badan, yang dapat dilihat, dibaca dan / atau dinikmati oleh umum. Pajak reklame dapat dikategorikan sebagai pajak daerah yang bersifat obyektif.

Penerimaan Pendapatan Asli Daerah, Pajak Daerah dan Pajak Reklame Kabupaten Magelang pada periode tahun anggaran 2010 2014, diketahui bahwa nilai dari Pendapatan Asli Daerah (PAD) lebih banyak mengalami peningkatan. Hal tersebut tidak jauh berbeda jika dibandingkan dengan pertumbuhan Pajak Daerah yang mengalami peningkatan yang cukup signifikan 4 tahun terakhir. Sementara perkembangan pajak reklame terhadap Pendapatan Asli Daerah dan Pajak Daerah pada tahun 2013 pajak reklame mengalami penurunan, namun realisasi penerimaan Pendapatan Asli Daerah dan Pajak Daerah mangalami peningkatan. Hal ini membuktikan bahwa pajak reklame bukan pajak unggulan di Kabupaten Magelang. Tetapi cukup menarik untuk diteliti, melihat kenyataan di lapangan banyak reklame di temukan di tempat-tempat umum maupun di ruas jalan.

Berdasarkan latar belakang di atas maka peneliti tertarik untuk mengadakan penelitian lebih lanjut, yang dituangkan dalam bentuk penelitian dengan judul " Analisis Faktor-faktor yang Mempengaruhi Penerimaan Pajak Reklame Kabupaten Magelang Periode 2010:M08 - 2014:M12. Tujuan yang ingin dicapai dengan penelitian ini adalah:

1. Untuk mengetahui interaksi dan hubungan jangka panjang PDRB terhadap penerimaan Pajak Reklame Kabupaten Magelang. 
2. Untuk mengetahui interaksi dan hubungan jangka panjang jumlah SIUP terhadap penerimaan Pajak Reklame Kabupaten Magelang.

3. Untuk mengetahui interaksi dan hubungan jangka panjang Jumlah Indusri terhadap penerimaan Pajak Reklame Kabupaten Magelang.
4. Untuk mengetahui interaksi dan hubungan jangka panjang PDRB, jumlah SIUP, dan Jumlah Industri terhadap penerimaan Pajak Reklame Kabupaten Magelang.

Secara skema kerangka pemikiran dapat digambarkan sebagai berikut:

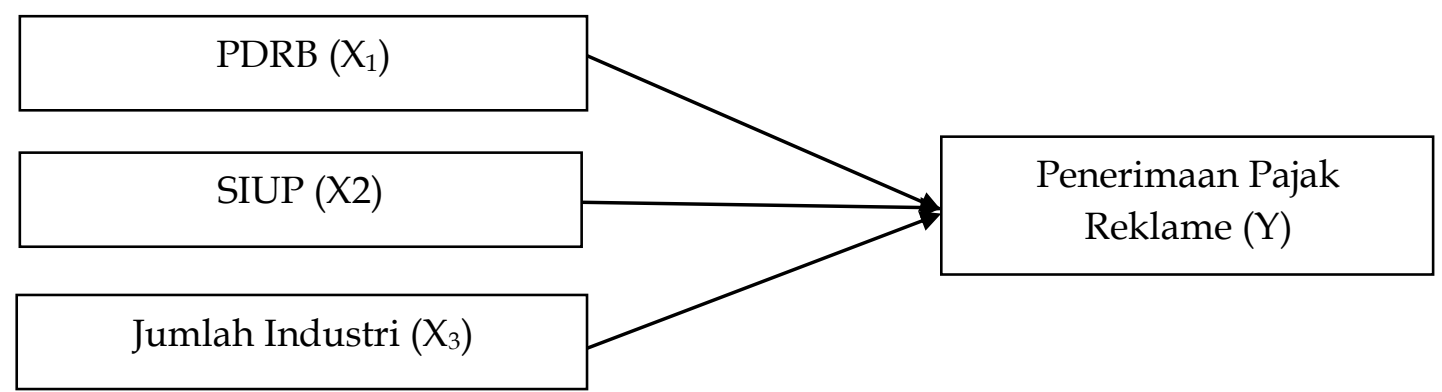

Gambar 1. Kerangka Pemikiran Penelitian

\section{METODE PENELITIAN}

Pendekatan yang digunakan dalam penelitian ini adalah pendekatan kuantitatif dan data yang digunakan adalah data sekunder. Data sekunder didapatkan dari instansi terkait seperti Dinas Pendapatan Pengelolaan Keuangan dan Asset Daerah (DPPKAD), Badan Penanaman Modal dan Pelayanan Perizinan Terpadu (BPMPPT) serta BPS Kabupaten Magelang. Variabel dependen yang digunakan dalam penelitian ini adalah penerimaan pajak reklame Kabupaten Magelang sedangkan variabel independen yang digunakan dalam penelitian ini adalah PDRB Kabupaten Magelang, jumlah Surat Izin Usaha Perdagangan (SIUP) Kabupaten Magelang, dan Industri di Kabupaten Magelang.
Metode analisis yang digunakan adalah Vector Auto Regressive (VAR)/ Vector Error Correction Model (VECM). Proses analisis VECM dilakukan melalui beberapa tahap yaitu dengan uji stasioneritas, uji penentuan lag, uji kointegrasi, uji kausalitas Granger, uji impulse response function, dan uji forecast error variance decomposition.

\section{HASIL DAN PEMBAHASAN}

\section{Uji Stasioneritas Data}

Pengujian dilakukan dengan menggunakan Augmented Dickey Fuller (ADF) dan Philips Perron (PP) dimana standar yang digunakan adalah nilai kritis (critical value). Apabila nilai mutlak t-statistic lebih besar nilai kritis McKinnon. Hasil pengujian ADF dan PP sebagai berikut:

Tabel 1. Hasil Uji Stasioneritas

\begin{tabular}{ccccccc}
\hline \multirow{2}{*}{ Variabel } & \multicolumn{2}{c}{ Level } & \multicolumn{2}{c}{ First Differrence } & \multicolumn{2}{c}{ Second Difference } \\
\cline { 2 - 7 } & ADF & PP & ADF & PP & ADF & PP \\
\hline RKLM & $-0,445191$ & $-0,899320$ & $-2,372565$ & $-3,680349$ & $-11,48567$ & $-14,79478$ \\
\hline PDRB & $-2,907447$ & $-2,074998$ & $-4,654470$ & $-4,685661$ & $-11,60693$ & $-19,38202$ \\
\hline SIUP & $-6,195749$ & $-6,540368$ & $-16,35138$ & $-24,06827$ & $-6,870665$ & $-56,73894$ \\
\hline IND & $-0,594043$ & $-0,416543$ & $-7,548540$ & $-7,747886$ & $-8,306624$ & $-12,0000$ \\
\hline
\end{tabular}

Sumber: Estimasi E-views 7.2 (diolah)

Tabel 1 menunjukkan bahwa keempat variabel (penerimaan pajak reklame, PDRB, Jumlah SIUP, dan Jumlah Industri) tidak stasioner pada tingkat level dan first difference. Pada tingkat second difference keempat variabel dinyatakan stasioner karena nilai t-statistic lebih besar dari nilai critical value McKinnon sebesar 5 persen yaitu $-2,918778$. 


\section{Uji Penentuan Lag Optimal}

Lag optimal digunakan untuk mengatasi masalah autokorelasi dalam uji VAR dan VECM. Estimasi VAR sangat peka terhadap panjang lag yang digunakan. Penetapan lag optimal berdasarkan pada nilai Likelihood Ratio
Test (LR), Final Prediction Error (FPE), Akaike Information Criteria (AIC), Schwarz Information Criterion (SC) dan Hannan Quinn (HQ). Penentuan lag optimal dapat dilihat pada Tabel berikut ini:

Tabel 2: Hasil Penentuan Lag Optimal

\begin{tabular}{ccccccc} 
Lag & LogL & LR & FPE & AIC & SC & HQ \\
\hline \hline 0 & -99.05893 & NA & 0.001038 & 4.480823 & 4.639835 & 4.540390 \\
1 & 182.9390 & $502.6919^{*}$ & $9.88 \mathrm{e}-09^{*}$ & $-7.084304^{*}$ & $-6.289242^{*}$ & $-6.786469^{*}$ \\
2 & 198.5948 & 25.18544 & $1.02 \mathrm{e}-08$ & -7.069339 & -5.638228 & -6.533237 \\
3 & 210.5154 & 17.10347 & $1.27 \mathrm{e}-08$ & -6.891974 & -4.824814 & -6.117603 \\
4 & 222.3228 & 14.88755 & $1.66 \mathrm{e}-08$ & -6.709686 & -4.006477 & -5.697047 \\
5 & 232.8084 & 11.39743 & $2.44 \mathrm{e}-08$ & -6.469931 & -3.130673 & -5.219025 \\
6 & 258.2192 & 23.20112 & $2.04 \mathrm{e}-08$ & -6.879094 & -2.903787 & -5.389920 \\
7 & 271.0922 & 9.514861 & $3.39 \mathrm{e}-08$ & -6.743139 & -2.131783 & -5.015698 \\
\hline \hline
\end{tabular}

* indicates lag order selected by the criterion Sumber: Eviews 7.2 (diolah)

Tabel 2 menunjukkan bahwa pada nilai LR, FPE, AIC, SC, dan HQ mereferensikan lag 1 sebagai lag optimal. Pemilihan lag 1 sebagai lag optimal karena berdasarkan hasil eviews, semua tanda bintang sejajar berada pada lag 1.

\section{Uji Kointegrasi}

Uji kointegrasi digunakan untuk mengindikasikan kemungkinan adanya hubungan keseimbangan jangka panjang antara variabel-variabel dalam penelitian ini. Hasil uji kointegrasi dapat dilihat dalam Tabel berikut ini

Tabel 3. Hasil Uji Kointegrasi

Unrestricted Cointegration Rank Test (Trace)

\begin{tabular}{ccccc}
\hline \hline $\begin{array}{c}\text { Hypothesized } \\
\text { No. of CE(s) }\end{array}$ & Eigenvalue & $\begin{array}{c}\text { Trace } \\
\text { Statistic }\end{array}$ & $\begin{array}{c}0.05 \\
\text { Critical Value }\end{array}$ & Prob.** $^{*}$ \\
\hline \hline None* & 0.614252 & 79.58784 & 47.85613 & 0.0000 \\
At most 1* & 0.403868 & 34.81694 & 29.79707 & 0.0121 \\
At most 2 & 0.191180 & 10.50419 & 15.49471 & 0.2439 \\
At most 3 & 0.011251 & 0.531781 & 3.841466 & 0.4659 \\
\hline \hline
\end{tabular}

Trace test indicates 2 cointegrating eqn(s) at the 0.05 level

* denotes rejection of the hypothesis at the 0.05 level

**MacKinnon-Haug-Michelis (1999) p-values 
Unrestricted Cointegration Rank Test (Maximum Eigenvalue)

\begin{tabular}{ccccc}
\hline \hline $\begin{array}{c}\text { Hypothesized } \\
\text { No. of CE(s) }\end{array}$ & Eigenvalue & $\begin{array}{c}\text { Max-Eigen } \\
\text { Statistic }\end{array}$ & $\begin{array}{c}0.05 \\
\text { Critical Value }\end{array}$ & Prob.** $^{*}$ \\
\hline \hline None * & 0.614252 & 44.77089 & 27.58434 & 0.0001 \\
At most 1 * & 0.403868 & 24.31275 & 21.13162 & 0.0172 \\
At most 2 & 0.191180 & 9.972413 & 14.26460 & 0.2138 \\
At most 3 & 0.011251 & 0.531781 & 3.841466 & 0.4659 \\
\hline \hline
\end{tabular}

Max-eigenvalue test indicates 2 cointegrating eqn(s) at the 0.05 level

* denotes rejection of the hypothesis at the 0.05 level

**MacKinnon-Haug-Michelis (1999) p-values

Sumber: Eviews 7.2 (diolah)

Tabel 3 dapat dilihat bahwa nilai trace statistic lebih besar critical value (nilai none dan at most 1) begitu juga dengan nilai max-eigen statistic lebih besar critical value sehingga hasil penelitian ini terjadi adanya keseimbangan jangka panjang sehingga model penelitian yang digunakan adalah Vector Error Correction Model (VECM).

Berdasarkan analisis ekonometrik di atas dapat dilihat bahwa di antara keempat variabel dalam penelitian ini, terdapat minimal satu kointegrasi pada tingkat signifikansi $5 \%$. Dengan demikian, dari hasil uji kointegrasi mengindikasikan bahwa diantara Pajak
Reklame, PDRB, Jumlah SIUP dan Industri memiliki hubungan stabilitas/ keseimbangan dan kesamaan pergerakan dalam jangka panjang. Dengan kalimat lain, dalam setiap periode jangka pendek, seluruh variabel cenderung menyesuaikan, untuk mencapai ekuilibrium jangka panjangnya.

\section{Uji Kasualitas Granger}

Uji kausalitas Granger digunakan untuk mengetahui apakah variabel-variabel dalam penelitian mempunyai hubungan satu arah saja ataukah dua arah. Hasil pengujian kausalitas Granger dapat dilihat pada Tabel berikut ini:

\section{Tabel 4. Hasil Uji Kasualitas Granger}

\begin{tabular}{lccc} 
Null Hypothesis: & Obs & F-Statistic & Prob. \\
\hline \hline LN_PDRB does not Granger Cause LN_RKLM & 52 & 0.33542 & 0.5651 \\
LN_RKLM does not Granger Cause LN_PDRB & 52 & 0.03386 & 0.8548 \\
\hline \hline SIUP does not Granger Cause LN_RKLM & 5835 & 0.0200 \\
LN_RKLM does not Granger Cause SIUP & \multirow{2}{*}{52} & 0.00184 & 0.9660 \\
\hline \hline IND does not Granger Cause LN_RKLM & & 1.13636 & 0.2916 \\
\hline LN_RKLM does not Granger Cause IND & &
\end{tabular}

Sumber: Eviews 7.2 (diolah)

Nilai probabilitas yang terdapat dalam 0,05 maka disimpulkan tidak terjadi kausalitas penelitian kausalitas Granger perlu diperhatikan. Jika nilai probabilitas lebih besar antar variabel. 
Hipotesis yang digunakan:

$\mathrm{H}_{0}$ :Variabel dependen tidak secara signifikan dipengaruhi oleh variabel independen.

$\mathrm{H}_{1} \quad$ :Variabel dependen secara signifikan dipengaruhi oleh variabel independen.

Dari Tabel di atas dapat dilihat bahwa variabel RKLM secara statistik tidak signifikan mempengaruhi PDRB dengan nilai prob sebesar $(0,5651)$ sehingga menerima hipotesi nol. Sedangkan PDRB secara statistik signifikan mempengaruhi RKLM $(0,0200)$ sehingga menolak hipotesis nol. Dengan demikian, disimpulkan bahwa terjadi kausalitas searah antara variabel RKLM dan PDRB yaitu hanya PDRB yang secara statistik signifikan mempengaruhi RKLM dan tidak berlaku sebaliknya.

Variabel RKLM secara statistik tidak signifikan mempengaruhi SIUP dengan nilai prob sebesar $(0,8548)$ sehingga menerima hipotesis nol. Sedangkan SIUP secara statistik signifikan mempengaruhi RKLM $(0,0113)$ sehingga menolak hipotesis nol. Dengan demikian, disimpulkan bahwa terjadi kausalitas searah antara variabel RKLM dan SIUP yaitu hanya SIUP yang secara statistik mempengaruhi RKLM dan tidak berlaku sebaliknya.

Variabel RKLM secara statistik tidak signifikan mempengaruhi IND dan begitu juga sebaliknya variabel IND secara statistik tidak signifikan mempengaruhi RKLM yang dibuktikan dengan nilai Prob masing-masing lebih besar dari 0,05 yaitu 0,9660 dan 0,2916 (hasil keduanya adalah menerima hipotesis nol). Sehingga dapat disimpulkan bahwa tidak terjadi kausalitas apapun untuk kedua variabel RKLM dan IND.

\section{Uji Impulse Responce Fuction (IRF)}

Impulse Responce Function (IRF) digunakan untuk mengGambarkan tingkat laju shock dari variabel yang digunakan dalam penelitian. Perilaku dinamis dari model VECM dapat dilihat melalui respon dari setiap variabel terhadap shock dari variabel tersebut maupun terhadap variabel endogen lainnya. Hasil dari Impulse Response Function (IRF) dapat dilihat pada gambar berikut ini:

\section{Gambar 2. Respon Penerimaan Pajak Reklame terhadap PDRB}

Response of LN_RKLMto LN_PDRB

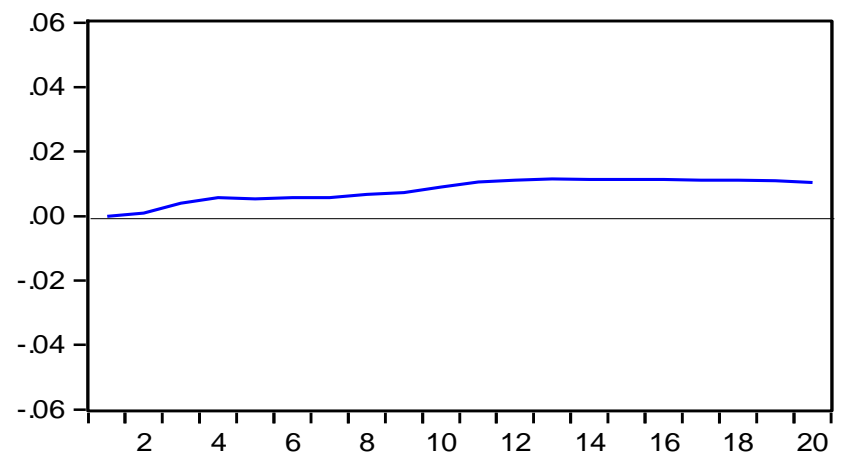

Sumber: Eviews 7.2 (diolah)

Pada Gambar 2 dapat dilihat bahwa penerimaan pajak reklame secara umum dapat merespon shock dari PDRB. Pada periode pertama penerimaan pajak reklame belum dapat merespon shock dari PDRB. Kemudian pada periode kedua, penerimaan pajak reklame mulai merespon shock dari PDRB secara positif. Peningkatan terjadi hingga periode keempat. Pada periode kelima hingga periode kedelapan respon penerimaan pajak reklame terhadap shock PDRB mengalami stagnan dan mulai periode selanjutnya mengalami peningkatan kembali. 


\section{Gambar 3. Respon Penerimaan Pajak Reklame Terhadap SIUP \\ Response of LN_RKLM to SIUP}

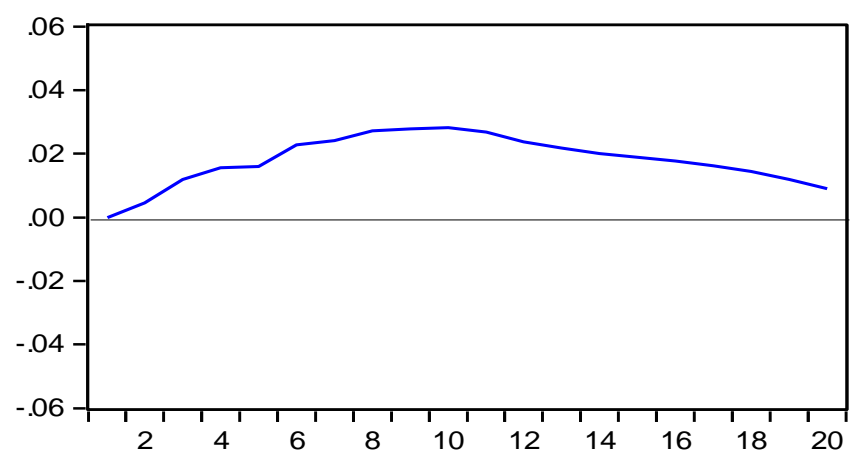

Sumber: Eviews 7.2 (diolah)

Pada Gambar 3 dapat dilihat bahwa penerimaan pajak reklame secara umum dapat merespon shock dari SIUP. Pada periode dapat merespon shock dari SIUP. Kemudian pada periode kedua, penerimaan pajak reklame mulai merespon shock dari SIUP secara positif. pertama penerimaan pajak reklame belum

\section{Gambar 4. Respon Penerimaan Pajak Reklame terhadap Industri}

Response of LN_RKLM to IND

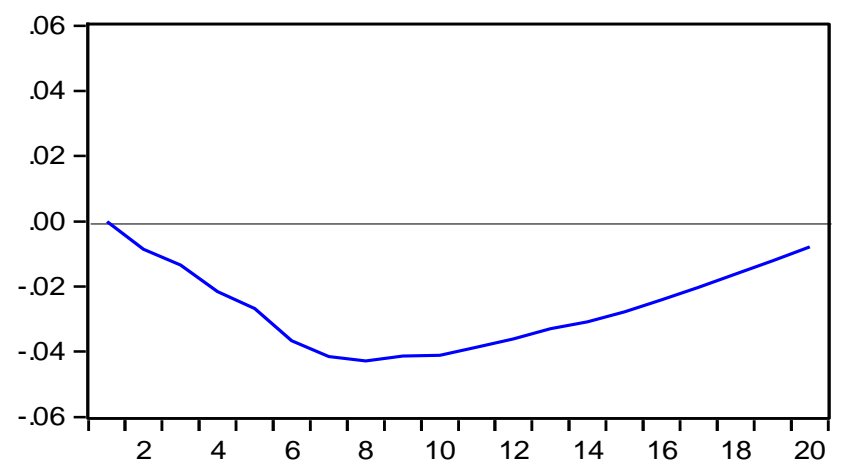

Sumber: Eviews 7.2 (diolah)

Pada Gambar 4 dapat dilihat bahwa penerimaan pajak reklame secara umum dapat merespon shock dari IND. Pada periode pertama penerimaan pajak reklame belum dapat merespon shock dari IND. Kemudian pada periode kedua, penerimaan pajak reklame mulai merespon shock dari IND secara negatif.

\section{Uji Forecast Error Variance Decomposition Model VECM}

Setelah menganalisis perilaku dinamis melalui Impulse Responce, selanjutnya akan dilihat karakteristik model melalui variance decomposition. Variance decomposition digunakan untuk menyusun forecast error variance suatu variabel, yaitu seberapa besar perbedaan antara variance sebelum dan sesudah shock, baik shock yang berasal dari diri sendiri maupun shock dari variabel lain untuk melihat pengaruh relatif variabel-variabel penelitian terhadap variabel lainnya. Hasil uji Variance Decomposition dapat dilihat pada Tabel 5 berikut ini: 
Tabel 5. Hasil Uji Forecast Error Variance Decomposition

\begin{tabular}{cccccc} 
Period & S.E. & LN_RKLM & LN_PDRB & SIUP & IND \\
\hline \hline & & & & & \\
2 & 0.026798 & 100.0000 & 0.000000 & 0.000000 & 0.000000 \\
11 & 0.039966 & 94.03826 & 0.057846 & 1.301978 & 4.601918 \\
12 & 0.184684 & 51.82764 & 1.272394 & 13.99802 & 32.90195 \\
14 & 0.194447 & 51.29196 & 1.478135 & 14.11187 & 33.11803 \\
16 & 0.209226 & 50.67729 & 1.870819 & 14.18808 & 33.26381 \\
19 & 0.218858 & 50.17301 & 2.242787 & 14.36707 & 33.21713 \\
20 & 0.225554 & 49.55345 & 2.829405 & 14.73136 & 32.88578 \\
& 0.226332 & 49.41011 & 3.022093 & 14.79026 & 32.77754
\end{tabular}

Sumber: Eviews 7.2 (diolah)

Tabel 5 dapat dijelaskan bahwa variabel yang mempunyai proporsi terbesar dalam mempengaruhi variabel penerimaan pajak reklame (LN_RKLM) adalah variabel pajak reklame itu sendiri. Pada periode pertama, variabel yang memberikan pengaruh terhadap penerimaan pajak reklame hanya penerimaan pajak reklame itu sendiri kemudian pada periode kedua variabel PDRB (LN_PDRB), jumlah SIUP (SIUP), dan industri mulai memberikan pengaruh terhadap penerimaan pajak reklame.

Variabel LN_PDRB (PDRB) mulai menjelaskan hubungannya terhadap penerimaan pajak reklame (LN_RKLM) pada periode kedua dimana variabel PDRB menjelaskan LN_RKLM sebesar 0,06 persen. Pada periode ketiga hingga keduapuluh, variabel PDRB mengalami peningkatan dalam menjelaskan hubungannya terhadap penerimaan pajak reklame dimana periode keduapuluh variabel PDRB dan pada periode keduapuluh variabel PDRB menjelaskan variabel pajak reklame sebesar 3,02 persen. Melihat hal ini, dapat disimpulkan bahwa PDRB signifikan dalam menjelaskan shock dari variabel penerimaan pajak reklame.

Variabel SIUP (Jumlah SIUP) pada periode kedua mulai menjelaskan bagaimana hubungannya terhadap LN_RKLM (penerimaan pajak reklame) sebesar 1,30 persen. Kemudian pada periode ketiga hingga keduapuluh, jumlah SIUP dalam menjelaskan hubungannya dengan penerimaan pajak reklame mengalami peningkatan dimana pada

periode keduapuluh, jumlah SIUP mampu menjelaskan sebesar 14,79 persen.

Variabel IND (industri) pada periode kedua mulai menjelaskan bagaimana hubungannya terhadap LN_RKLM (penerimaan pajak reklame) sebesar 4,60 persen. Pada periode ketiga hingga keempatbelas, variabel industri mengalami peningkatan dalam menjelaskan hubungannya terhadap penerimaan pajak reklame dimana periode keempatbelas variabel Industri menjelaskan variabel pajak reklame sebesar 33,26 persen. Kemudian pada periode keenambelas hingga keduapuluh mengalami penurunan, dalam menjelaskan hubungannya terhadap pajak reklame dimana periode keduapuluh variabel industri menjelaskan variabel pajak reklame sebesar 32,77 persen. Maka dengan ini dapat disimpulkan bahwa industri tidak signifikan dalam menjelaskan shock dari variabel penerimaan pajak reklame.

\section{Pengaruh PDRB terhadap Penerimaan Pajak Reklame \\ Dari hasil penelitian menunjukkan bahwa} PDRB Kabupaten Magelang mempunyai hubungan yang searah dengan penerimaan pajak reklame, hal ini dapat dilihat pada uji kasualitas Granger. Berdasarkan hasil uji impulse response function dan variance decomposition goncangan yang terjadi pada PDRB direspon secara positif.

PDRB merupakan suatu tolak ukur kemakmuran bagi suatu daerah. Semakin tinggi PDRB suatu daerah mengindikasikan semakin tingginya tingkat pendapatan dan kemajuan 
suatu daerah. PDRB yang tinggi mencerminkan keadaan perekonomian dan pergerakan sektorsektor ekonomi yang baik. Keadaan ini didorong oleh investasi yang selanjutnya akan meninggikan tingkat kegiatan ekonomi daerah dan berakibat pendapatan masyarakat bertambah dan seterusnya konsumsi masyarakat bertambah tinggi. Kenaikan ini akan menghasilkan lebih banyak barang dan jasa dan terciptanya penanaman modal baru.

\section{Pengaruh SIUP terhadap Penerimaan Pajak Reklame}

Berdasarkan hasil dari impulse respon function penerimaan pajak reklame merespon positif shock dari jumlah SIUP. Hal ini juga dirasakan pada hasil variance decomposition dimana jumlah industri selalu terjadi peningkatan dalam menjelaskan hubungannya.

Dalam jangka panjang jumlah SIUP berpengaruh positif terhadap penerimaan pajak reklame Kabupaten Magelang dan ini berarti pertumbuhan jumlah SIUP memberikan kontribusi terhadap penerimaan pajak reklame. Hal ini sependapat dengan Phany Ineke Putri (2013) bahwa jumlah SIUP berpengaruh signifikan terhadap penerimaan pajak reklame.

Dalam pemasangan reklame harus memiliki syarat dalam perizinan yaitu reklame yang telah dilaporkan adalah reklame yang sudah memiliki stampel serta tanda tangan dari pihak Badan Penanaman Modal dan Perizinan Terpadu (BPMPPT) pada reklame yang dipasang. Dalam hal ini salah satu syarat izin reklame harus memiliki Surat Izin Usaha Perdagangan (SIUP) tersebut.

\section{Pengaruh Industri terhadap Penerimaan Pajak Reklame}

Berdasar pada pernyataan Sutrisno yang menyatakan jumlah insustri mempengaruhi penerimaan pajak reklame maka penelitian ini tidak sejalan dengan teori pernyataan Sutrisno. Jumlah industri pada kausalitas Granger tidak terjadi kausalitas apapun untuk kedua variabel. Dimana jumlah industri tidak mempengaruhi penerimaan pajak reklame begitu juga dengan penerimaan pajak reklame tidak mempengaruhi pajak reklame.

Berdasarkan hasil impulse response function (IRF) dan variance decomposition dapat di lihat bahwa pengaruh jumlah industri terhadap penerimaan pajak reklame sudah dapat dirasakan pada periode kedua. Dimana pada hasil IRF penerimaan pajak reklame merespon negatif dari industri. Sedangkan pada hasil FEVD dapat dilihat bahwa jumlah industri yang selalu mengalami kenaikan namun juga mengalami penurunan.

Dalam jangka panjang menunjukkan bahwa jumlah industri berpengaruh secara negatif terhadap penerimaan pajak reklame Kabupaten Magelang dan ini berarti adanya pertumbuhan jumlah industri tidak mempengaruhi penerimaan pajak reklame. Hal ini dapat terjadi karena dalam menentukan lokasi industri, yang dilihat dari para pemilik industri adalah faktor biaya yang akan mereka keluarkan dimana para pemilik industri akan berusaha untuk meminimumkan biaya mereka demi mencapai keuntungan maksimum. Selain biaya yang menjadi kendala faktor perubahan kebijakan atau regulasi pemerintah.

Di Kabupaten Magelang, regulasi yang mendasari pemungutan pajak reklame tentu akan mengalami perubahan terutama regulasi mengenai tarif pajak reklame. Perubahan tarif dilakukan oleh pemerintah untuk meningkatkan pendapatan pajak daerah tetapi perubahan ini dinilai negatif oleh pemilik industri karena dengan adanya perubahan dalam tarif dimana tarif akan dinaikkan maka dalam hal ini berdampak pada biaya yang harus dikeluarkan industri terutama biaya dalam pengenalan barang dan jasa kemasyarakat.

Peningkatan biaya ini tentunya akan membuat keuntungan yang diperoleh industri menurun dan hal ini pasti tidak diinginkan oleh industri. Sehingga cara yang ditempuh pihak industri dengan tidak melaporkan dengan benar jumlah reklame yang mereka pasang. Adanya pemasangan reklame tanpa izin merupakan salah satu indikator berkurangnya penerimaan pajak reklame. Hal ini bisa disebabkan kurangnya pemahaman masyarakat terhadap peraturan yang diterapkan dan bisa juga kesengajaan dari pihak pemasang reklame.

\section{SIMPULAN}

Berdasarkan hasil uji hipotesis dan pembahasan pada bab sebelumnya, maka penelitian ini dapat diambil kesimpulan sebagai berikut: adanya interaksi dan hubungan jangka panjang anatara PDRB dan jumlah SIUP 
terhadap penerimaan pajak reklame namun untuk jumlah industri tidak berpengaruh terhadap penerimaan pajak reklame.

\section{Saran}

Berdasarkan kesimpulan di atas, sebagai masukan bagi Pemerintah Kabupaten Magelang dalam upaya peningkatan penerimaan pajak reklame, maka dapat disarankan sebagai berikut:

a. Meningkatkan peran faktor-faktor yang mempengaruhi penerimaan pajak reklame. Menjaga pertumbuhan PDRB Kabupaten Magelang bahkan meningkatkan yang secara tidak langsung akan mempengaruhi penerimaan pajak reklame.

b. Mengintensifkan dan meningkatkan peran industri sehingga dapat memberikan kontribusi yang maksimal terhadap penerimaan pajak reklame Kabupaten Magelang.

\section{DAFTAR PUSTAKA}

Arsyad, Lincolin. 2010. Ekonomi Pembangunan. Edisi Kelima. Cetakan Pertama. UPP STIM YKPN. Yogyakarta.

Ascarya, 2009. Aplikasi Vector Autoregression dan Vector Error Correction Model menggunakan Eviews 4.1. Pdf

Badan Pusat Statistik. Indikator Ekonomi Kabupaten Magelang Berbagai Tahun. Magelang.

. Kabupaten Magelang dalam Angka Berbagai Tahun.Magelang. . Produk Domestik Regional Bruto Kabupaten Magelang Menurut Lapangan Usaha Berbagai Tahun. Magelang.

Darise, Nurlan. 2007. Pengelolaan Keuangan Daerah. Cetakan Kedua. Penerbit Indeks. Jakarta.

Dumairy. 1999. Perekonomian Indonesia. Erlangga. Jakarta.

Direktorat Jenderal Pajak - Kementrian Keuangan. Buku Panduan Hak dan Kewajiban Wajib Pajak, http://www.pajak.go.id/sites/default/ files/HKWP-Bab1_1.pdf (diakses tanggal 10 November 2015)

Gujarati, Damador N. 2010. Dasar-dasar Ekonometrika Buku 1. Edisi 5. Terjemahan Eugenia Mardanugraha Dkk. Salemba Empat. Jakarta.
Kuncoro, Mudrajad. 2009. Metode Riset untuk Bisnis dan Ekonomi, Bagaimana Meneliti dan Menulis Tesis ?. Erlangga. Jakarta

Mangkoesoebroto, Guritno. 2010. Ekonomi Publik. Edisi Ketiga. Cetakan Ketiga belas. BPFE. Yogyakarta.

Mardiasmo. 2009. Perpajakan. Edisi 2009. Cetakan pertama. Penerbit Andi Offset. Yogyakarta.

. 2004. Otonomi dan Manajamen Keuangan Daerah. Penerbit Andi Offset. Yogyakarta.

Mulyadi. 2012. Ekonomi Sumber Daya Manusia. Cetakan kelima. Penerbit RajaGrafindo. Jakarta.

Nurmayasari, Dini. 2010. Analisa Penerimaan Pajak Reklame Kota Semarang. Skripsi. Fakultas Ekonomi Universitas Diponegoro. Semarang.

Pemerintah Kota Yogyakarta. 2012. Buku Data Status Lingkungan Hidup Kota Yogyakarta Tahun 2012. Yogyakarta

Peraturan Kabupaten Magelang Nomor 13 Tahun 2010 tentang Pajak Daerah.

Puspitaningsih, Silvia R. 2013. Analisa Penerimaan Pajak Reklame Kota Malang. Jurnal Ilmiah. Fakultas Ekonomi dan Bisnis Universitas Brawijaya. Malang.

Sukirno, Sadono. 2011. Makroekonomi Teori Pengantar. Edisi ketiga. Cetakan ke-20. PT RajaGrafindo Persada. Jakarta.

Waluyo.2008. Perpajakan Indonesia Buku 1. Edisi 8. Cetakan pertama. Salemba Empat. Jakarta.

Waluyo, Budi. 2011. Pengaruh Pajak Reklame, Pajak Restoran, Retribusi Jasa Umum, Jumlah Penduduk, dan Jumlah Industri Terhadap Pendapatan Asli Daerah (PAD) Kota Depok Jawa Barat. Fakultas Ekonomi Universitas Gunadarma Jakarta. 